\title{
Analisis Pemberdayaan Masyarakat di Bidang Kesehatan
}

\section{Analysis of Community Empowerment in Health Sector}

\author{
Tuti Restuastuti ${ }^{1}$, Zahtamal ${ }^{1}$, Fifia Chandra ${ }^{1}$, Ridha Restila ${ }^{1}$ \\ ${ }^{1}$ Kelompok Jabatan Fungsional (KJF) Ilmu Kesehatan Masyarakat-Kedokteran Komunitas
}

Fakultas Kedokteran Universitas Riau

\begin{abstract}
ABSTRAK
Pemberdayaan masyarakat merupakan lini terdepan dalam promosi kesehatan dan wajib dilaksanakan oleh seluruh puskesmas. KepMenKes no 128/MenKes/SK/2/2004, Dinas Kesehatan bertanggung jawab menyelenggarakan kesehatan masyarakat, salah satu fungsi peran puskesmas merupakan pusat pemberdayaan masyarakat dengan strategi kemitraan dengan kelompok masyarakat. Penelitian ini bertujuan menggambarkan pemberdayaan masyarakat dalam bidang kesehatan di Kota Pekanbaru.Penelitian ini merupakan penelitian deskriptif dengan menggunakan metode survei.Sampel penelitian adalah sepuluh puskesmas di Kota Pekanbaru, pengambilan data dilakukan dengan cara pengisian kuesioner, catatan program dan data sekunder dari profil Puskesmas. Hasilnya dari delapan Organisasi Masyarakat, untuk Posyandu seluruh Puskesmas sudah dilaksanakan. Gambaran aspek pemberdayaan masyarakat di Kota Pekanbaru yang terdiri dari (3 aspek) : keaktifan tokoh masyarakat, ketersediaan organisasi kemasyarakatan dan UKBM, pemanfaatan sarana dan material dari masyarakat sudah terlaksana secara optimal. Namun, pada 4 aspek, yaitu ketersediaan dana masyarakat, penggunaan pengetahuan masyarakat, teknologi dari masyarakat, dan pembuatan keputusan oleh masyarakat belum terlaksana seluruhnya. Masih banyak kegiatan organisasi dan UKBM yang tidak berjalan optimal kecuali posyandu aktif. UKBM polindes masih sangat sedikit dilakukan di wilayah kerja puskesmas di Kota Pekanbaru. Keterkaitan pelaksanaan fungsi pemberdayaan oleh puskesmas dengan sumber daya dan proses manajerial puskesmas sudah dalam kategori baik. Sedangkan pada ketersediaan jejaring dan organisasi termasuk kategori cukup
\end{abstract}

Kata kunci: Pemberdayaan Masyarakat, UKBM, Puskesmas

\begin{abstract}
Community empowerment is a leader in health promotion and must be implemented by all health centers. Minister of Health Decree No. 128 / Menkes / SK / 2/2004, the Department of Health responsible for organizing the public health, one of the functions of health centers as a central with community empowerment partnerships in community groups. Aims of this studywas to describe the community empowerment in the health sector in Pekanbaru City, this research is a descriptive study by using research survey.Sampel consist of ten health centers. The data was collected by filling out the questionnaire, program notes and secondary data from Public Health center's profile. The result of eight community organizations, Posyandu have been implemented in all health centers. Overview aspects of community development in the city of Pekanbaru were consisting of ( 3 aspects): the liveliness of community leaders, community organizations and UKBM availability, utilization of facilities and material from the public has been implemented optimally. But in (4 aspects): the availability of public funds, use of public knowledge and technology from the public, and making decision by the public have not been implemented yet entirely. There are still plenty of activities and organizations that did not run optimally yet except posyandu had been actived. UKBM Polindes is not fully done in the working area of health centers in Pekanbaru. Linkage implementation of central public health's empowerment function by using the resources and central public health mangerial process had a good category While the availability of networks and organizations are still in moderate category.
\end{abstract}

Keywords: Community empowerment, UKBM, public health center

Korespondensi : Tuti Restuastuti, email: ny.totoktuti@yahoo.com

Artikel info: Online published first 14 September 2017.

DOI: https://doi.org/10.26891/jkm.v1i1.2017.14-19

Copyright @ 2017 Authors. This is an open access article distributed under the terms of the Creative Commons Attribution-NonCommercial 4.0 International License (http://creativecommons.org/licenses/by-nc/4.0/), which permits unrestricted non-commercial use, distribution, and reproduction in any medium, provided the original author and source are properly cited. 
Pembangunan kesehatan adalah bagian dari pembangunan nasional yang bertujuan meningkatkan kesadaran, kemauan dan kemampuan hidup sehat bagi setiap orang agar terwujud derajat kesehatan masyarakat yang tinggi. Namun, sebagian masyarakat masih mengalami keterbatasan dalam memperoleh pelayanan kesehatan sehingga tidak mengherankan jika kondisi kesehatan masyarakat kurang begitu baik, tidak sesuai dengan yang di harapkan oleh pemerintah.

Pusat Kesehatan Masyarakat (Puskesmas) adalah Unit Pelaksana Teknis (UPT) Dinas Kesehatan yang ada di Kabupaten/Kota, mempunyai tanggung jawab menyelenggarakan pembangunan kesehatan di satu wilayah kecamatan melalui pemberdayaan masyarakat sesuai dengan Kepmenkes No 128/Menkes/SK/II/2004 tentang Puskesmas dan salah satu fungsi peran puskesmas merupakan pusat pemberdayaan masyarakat dengan strategi kemitraan dengan kelompok masyarakat. ${ }^{1}$

Banyak model dan strategi pemberdayaan masyarakat yang telah dikembangkan, khususnya di bidang kesehatan. Kota Pekanbaru merupakan salah satu kota besar di Indonesia mempunyai 20 puskesmas dengan beberapa model pemberdayaan masyarakat yang dilaksanakan dalam bentuk Upaya Kesehatan Bersumberdaya Manusia (UKBM), antara lain: Pos Pelayanan Terpadu (Posyandu) dengan klasifikasi: Pratama, Madya, Purnama maupun Mandiri, Pos Pembinaan Terpadu; Lanjut Usia (Posyandu Lansia); Kelurahan/Desa Siaga aktif; Pondok Bersalin Desa (Polindes dan KBKIA); Pendidikan Anak Usia Dini (PAUD); Pos Obat Desa (POD), Pos Upaya Kesehatan Kerja (Pos UKK), Taman Obat Keluarga (TOGA), Pemantauan dan Stimulasi Perkembangan Balita (PSPB), Keluarga Mandiri, Pos Kesehatan Pesantren (Poskestren), Dana Sehat serta Lembaga Swadaya Masyarakat (LSM) yang bergerak dibidang kesehatan. ${ }^{2,3}$

Puskesmas melaksanakan tugas yang dilimpahkan bekerjasama dengan pihak kecamatan yang ada diwilayah kerjanya dengan membentuk kader-kader kesehatan seperti: kader posyandu, kader posyandu usila, kader jumantik, kader TB, kader gizi, kader kesehatan lingkungan dan kader HIV/AIDS. Untuk mengetahui sampai sejauh mana pelaksanaan kegiatan yang sudah terbentuk, maka secara rutin Dinas Kesehatan Kota Pekanbaru telah melakukan penilaian mulai tingkat kota, provinsi dan nasional. Tahun 2015 untuk Posyandu Parasnya Elok Bagai Dari Sifat, Kelurahan Tanjung Rhu RW7 telah memenangkan lomba posyandu tingkat Kota Pekanbaru, tingkat Propinsi Riau dan sekarang sedang dalam penilaian tingkat Nasional. Hingga saat ini, kebanyakan program pemberdayaan masyarakat berfokus pada pengukuran hasil akhir seperti cakupan program, perilaku hidup sehat atau indikator penyakit. Ede, dkk yang dilakukan pada tahun 2012, mencoba mengukur tingkat pemberdayaan masyarakat dalam sektor kesehatan dengan menggunakan instrumen yang mengandung 7 unsur pemberdayaan masyarakat yang ditetapkan oleh Kementerian Kesehatan
Republik Indonesia tahun 1999,tentang panduan umum pemberdayaan masyarakat 3,4 .

Pemberdayaan masyarakat dibidang kesehatan merupakan upaya pengembangan pengetahuan, sikap dan perilaku masyarakat agar lebih berkemampuan menangani persolan kesehatan yang dihadapi. Penelitian ini bertujuan untuk mengetahui gambaran pemberdayaan masyarakat dalam bidang kesehatan oleh puskesmas di Kota Pekanbaru

Pemberdayaan masyarakat telah diketahui oleh seluruh puskesmas di Indonesia, namun berdasarkan kenyataan bahwa pemberdayaan masyarakat yang menjadi salah satu fungsi puskesmas dan telah cukup lama diperkenalkan tetapi keadaan sebenarnya ditingkat pembuat kebijakan didaerah dan masyarakat masih belum banyak diketahui. Kondisi ini menyebabkan timbulnya kesulitan dalam penilaian dan pembuatan program untuk meningkatkan kualitas upaya pemberdayaan masyarakat

\section{METODE}

Penelitian ini penelitian deskriptif dengan metode survei. Penelitian deskriptif dilakukan untuk melihat gambaran pemberdayaan masyarakat dalam bidang kesehatan di puskesmas Kota Pekanbaru dengan waktu penelitian selama 6 bulan. Pengumpulan data tentang pemberdayaan masyarakat ini didapatkan dari catatan program dan kegiatan serta pengisian kuesioner di 10 Puskesmas yang ada di Kota Pekanbaru. Alur penelitian ada beberapa tahap. Tahap awal dilakukan pengisian format isian yang memuat 7 potensi masyarakat oleh petugas Puskesmas dengan melihat catatan program Puskesmas. Selanjutnya, untuk menilai fungsi pelaksanaan pemberdayaan masyarakat oleh puskesmas dilakukan isian oleh kepala Puskesmas menggunakan lembar pernyataan yang telah disiapkan. Fungsi pelaksanaan pemberdayaan masyarakat oleh puskesmas mencakup ketersediaan sumber daya, proses manajerial puskesmas, dan ketersediaan jejaring kerja dan organisasi.

Pada tahap berikutnya dilakukan analisa deskriptif terhadap pemenuhan 7 komponen organisasi masyarakat yang ditentukan dengan berbagai kriteria. Kemudian analisa deskriptif juga dilakukan terhadap jenis organisasi dan UKBM yang dilaksanakan di tiap puskesmas. Analisa terhadap pernyataan kepala puskemas di sajikan dalam bentuk total scoring. Data yang sudah didapat dianalisis secara deskriptif dengan menggunakan distribusi dan frekuensi untuk setiap variabel untuk menggambarkan tentang pemberdayaan masyarakat yang telah dilaksanakan oleh 10 Puskesmas yang ada di Kota Pekanbaru.

\section{HASIL}

Berdasarkan hasil penelitian yang dilakukan di 10 puskesmas di kota Pekanbaru, menunjukkan gambaran tujuh aspek pemberdayaan masyarakat sebagian besar kegiatan belum terlaksana dengan baik (Tabel 1). Terdapat tiga aspek pemberdayaan yang telah dilakukan 
oleh seluruh Puskesmas yang diteliti, yaitu keaktifan tokoh masyarakat, ketersediaan organisasi kemasyarakatan dan UKBM, serta pemanfaatan sarana dan material dari masyarakat. Aspek pengetahuan dan teknologi dari masyarakat hanya dilakukan oleh delapan dari 10 puskesmas, sedangkan untuk aspek ketersediaan dana dan pembuatan keputusan masyarakat dilakukan oleh tujuh dan enam puskesmas.

Tabel 1. Gambaran Aspek Pemberdayaan Masyarakat

\begin{tabular}{clcc}
\hline No & \multicolumn{1}{c}{ Variabel } & Ada & \% \\
\hline 1 & $\begin{array}{l}\text { Keaktifan Tokoh } \\
\text { Masyarakat }\end{array}$ & 10 & 100 \\
2 & $\begin{array}{l}\text { Ketersediaan organisasi } \\
\text { kemasyarakatan dan } \\
\text { UKBM }\end{array}$ & 10 & 100 \\
3 & $\begin{array}{l}\text { Ketersediaan dana } \\
\text { masyarakat }\end{array}$ & 7 & 70 \\
4 & $\begin{array}{l}\text { Pemanfaatan sarana } \\
\text { dan material dari } \\
\text { masyarakat }\end{array}$ & 10 & 100 \\
5 & $\begin{array}{l}\text { Penggunaan } \\
\text { pengetahuan } \\
\text { masyarakat }\end{array}$ & 8 & 80 \\
7 & $\begin{array}{l}\text { Teknologi dari } \\
\text { masyarakat } \\
\text { Pembuatan keputusan } \\
\text { oleh masyarakat }\end{array}$ & 6 & 60 \\
\hline
\end{tabular}

Setelah dilakukan penilaian terhadap kegiatan pemberdayaan masyarakat, maka dilakukan observasi lebih lanjut mengenai jenis organisasi kemasyarakatan dan UKBM yang berjalan di wilayah kerja puskesmas (Gambar 1). Jenis organisasi yang dinilai adalah posyandu aktif, perkumpulan pemuda, KBKIA, PAUD, LSM/LSBM, Polindes, Desa/RW siaga, dan Poskesdes. Dari UKBM yang dilaksanakan hanya posyandu yang berjalan di semua puskesmas. Untuk UKBM desa/RW siaga telah dilaksanakan oleh 8 puskesmas. Organisasi dan UKBM perkumpulan pemuda hanya terdapat di 6 puskesmas. Poskesdes sudah terlaksana di 5 puskesmas. KBKA dan LSM/LSBM masing - masing terlaksana di 4 puskesmas. UBKM paling sedikit terlaksana di wilayah kerja puskesmas adalah Polindes yang hanya terdapat di 2 puskesmas saja.

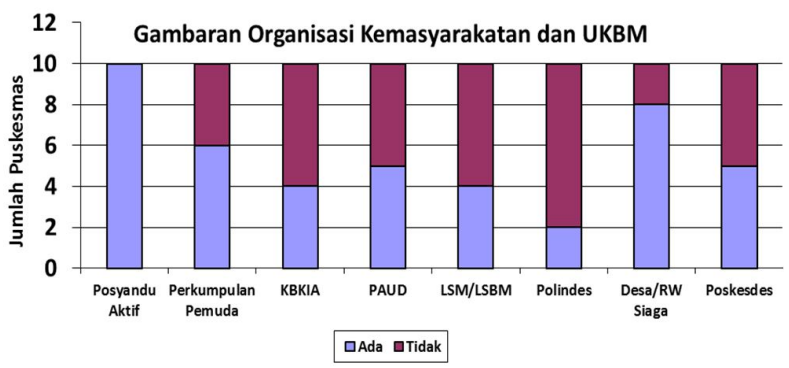

Gambar 1. Gambaran organisasi kemasyarakatan dan UKBM di 10 Puskesmas Kota Pekanbaru Tahun 2016

Analisis deskriptif penelitian juga dilakukan terhadap ketersediaan sumber daya, proses manajerial puskesmas dan ketersediaan jejaring kerja dan organisasi. Data diperoleh berdasarkan hasil wawacara dengan pihak puskesmas. Dari hasil penelitian terlihat gambaran ketersediaan sumber daya 9 Puskesmas dalam kategori baik dengan skor total penilain antara 55 sampai 96 , proses manajerial Puskesmas 9 Puskesmas dalam kategori baik dengan skor total penilaian antara 61 sampai 82, dan pada ketersediaan jejaring kerja dan organisasi terdapat 4 Puskesmas kategori baik dan 6 kategori cukup dengan skor total penilaian antara 58 sampai 82

Tabel 2 Skor Ketersediaan Sumber Daya Puskesmas, Proses Manajerial dan ketersediaan jejaring kerja dan organisasi di 10 Puskesmas Kota Pekanbaru

\begin{tabular}{lcccccc}
\hline Puskesmas & \multicolumn{2}{c}{$\begin{array}{l}\text { Ketersediaan } \\
\text { Sumber Daya }\end{array}$} & \multicolumn{2}{c}{$\begin{array}{c}\text { Proses Manejerial } \\
\text { Puskesmas }\end{array}$} & $\begin{array}{c}\text { Ketersediaan } \\
\text { Jejaring kerja dan } \\
\text { Organisasi }\end{array}$ \\
\hline Rumbai P & 55 & Cukup & 61 & Cukup & 52 & Cukup \\
Simpang Baru & 82 & Baik & 77 & Baik & 58 & Cukup \\
Sidomulyo RI & 75 & Baik & 74 & Baik & 88 & Baik \\
Rumbai Bukit & 77 & Baik & 79 & Baik & 63 & Cukup \\
Tenayan Raya & 89 & Baik & 82 & Baik & 75 & Baik \\
Sidomulyo RJ & 96 & Baik & 79 & Baik & 54 & Cukup \\
Langsat & 75 & Baik & 77 & Baik & 62 & Cukup \\
Melur & 71 & Baik & 74 & Baik & 64 & Cukup \\
Senapelan & 77 & Baik & 80 & Baik & 75 & Baik \\
Muara Fajar & 76 & Baik & 81 & Baik & 71 & Baik \\
\hline
\end{tabular}

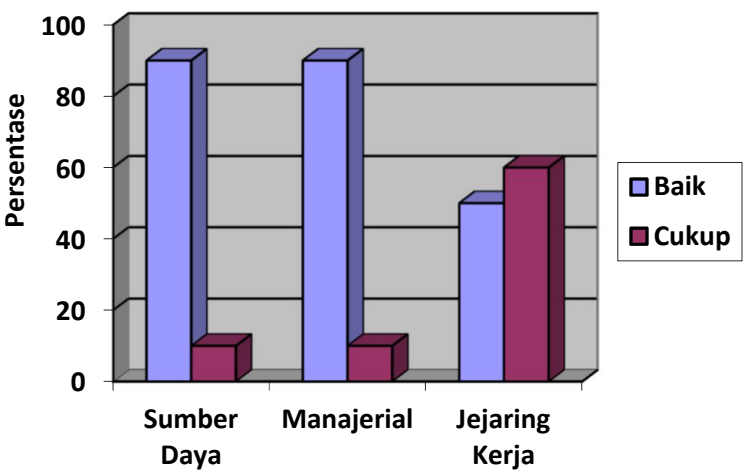

Gambar 2. Ketersediaan Sumber Daya Puskesmas, Proses Manejerial dan Ketersediaan Jejaring Kerjadan Organisasi di 10 Puskesmas Kota Pekanbaru Tahun 2016

\section{DISKUSI}

Pemberdayaan masyarakat adalah proses pemberian informasi secara terus menerus dan berkesinambungan mengikuti perkembangan sasaran serta proses membantu sasaran, agar sasaran tersebut berubah dari tidak tahu menjadi tahu/sadar (aspek pengetahuan), dari tahu menjadi mau (aspek sikap) dan dari mau menjadi mampu melaksanakan perilaku yang diperkenalkan (aspek tindakan). ${ }^{5}$ Menurut Wiku Adisamito dalam dimensi kesehatan, "pemberdayaan masyarakat merupakan proses yang dilakukan oleh masyarakat (dengan atau tanpa campur tangan pihak luar) untuk memperbaiki kondisi lingkungan, sanitasi dan aspek lainnya yang secara langsung maupun tidak langsung berpengaruh dalam kesehatan masyarakat'. Dalam upaya pemberdayaan masyarakat, Wiku Adisamito juga menekankan perlu diperhatikan empat (4) unsur pokok utama, yaitu aksesibilitas informasi, keterlibatan dan partisipasi, akuntabilitas dan kapasitas organisasi lokal, agar tercapai tujuan pemberdayaan masyarakat. 5,6 
Sasaran utama pemberdayaan adalah individu dan keluarga serta kelompok masyarakat. Dalam mengupayakan agar seseorang tahu dan sadar, kuncinya terletak pada keberhasilan membuat orang tersebut memahami bahwa sesuatu adalah masalah baginya dan bagi masyarakat. Sepanjang orang tersebut belum mengetahui dan menyadari bahwa sesuatu itu merupakan masalah, maka orang tersebut tidak akan bersedia menerima informasi apapun lebih lanjut, manakala ia telah menyadari masalah yang dihadapinya maka kepadanya harus diberikan informasi umum lebih lanjut tentang masalah yang bersangkutan. ${ }^{3}$

Hasil penelitian dari Ede,dkk.memperlihatkan bahwa tingkat pemberayaan masyarakat diwilayah kerja puskesmas di Depok umumnya banyak yang memenuhi kategori baik, sebaliknya hasil yang didapat dipuskesmas Jakarta Selatan banyak kategori kurang. ${ }^{3}$ Dalam penelitian ini pengukuran pemberdayaan masyarakat yang akan digunakan adalah format yang telah dikembangkan dan dimodifikasikan oleh Ede, dkk berdasarkan pada panduan pemberdayaan masyarakat menurut Kementerian Kesehatan Republik Indonesia yang terdiri dari 7 komponen potensi masyarakat yaitu (1) keberadaan tokoh masyarakat dan kader kesehatan, (2) keberadaan organisasi masyarakat termasuk upaya kesehatan bersumber daya masyarakat (UKBM), (3) kesediaan dana masyarakat, (4) kesediaan sarana dan materi dari masyarakat, (5) tingkat pengetahuan masyarakat, (6) kesediaan teknologi dari masyarakat, dan (7) pembuatan keputusan oleh masyarakat. ${ }^{7}$ Permendagri RI Nomor 7 Tahun 2007 tentang kader pemberdayaan masyarakat menyatakan bahwa dalam rangka pertumbuhkembangan, penggerakan prakarsa dan partisipasi masyarakat serta swadaya gotong royong dalam pembangunan di desa dan kelurahan perlu dibentuk kader pemberdayaan masyarakat desa. Kader pemberdayaan masyarakat merupakan mitra pemerintahan desa dan kelurahan yang diperlukan keberadaan dan peranannya dalam pemberdayaan masyarakat dan pembangunan partisipatif di desa dan kelurahan. Peran kader tersebut adalah mempercepat perubahan, perantaraan, pendidik, perencana, advokasi, aktivis dan pelaksana teknis.

Terdapat beberapa hal yang perlu diperhatikan dalam mengukur tingkat pemberdayaan masyarakat dalam bidang kesehatan, antara lain efektivitas dari komponen intervensi, sasaran kelompok masyarakat dan lokasi intervensi, sesuai dengan Kepmenkes Republik Indonesia tahun 2010 tentang Pedoman umum pengembangan desa dan kelurahan siaga aktif, bahwa petugas dan kader yang bekerja mengembangkan kegiatan dimasyarakat seperti posyandu dan desa siaga adalah orang yang sama. Perlu upaya penyamaan kebijakan termasuk penamaan program desa siaga yang umumnya belum banyak dikenal oleh para pembuat kebijakan didaerah,terlebih lagi masyarakat. Salah satu metode yang dapat dilakukan dalam memberdayakan masyarakat adalah melalui pelatihan untuk meningkatkan kompetensi, baik dari pengetahuan maupun keterampilan mereka. ${ }^{8}$ Walaupun belum memberikan instrumen yang jelas, Phil Barte mengenalkan 16 elemen pemberdayaan masyarakat yang menekankan pentingnya mengukur pemberdayaan masyarakat berdasarkan potensi dan kondisi yang ada pada masyarakat. ${ }^{9}$.

Berdasarkan hasil penelitian ini diketahui bahwa aspek pemberdayaan masyarakat sudah mendapatkan modal yang cukup kuat berupa adanya dukungan dari tokoh masyarakat dan sarana yang akan berdampak pada keberhasian upaya pemberdayaan yang dilakukan. Hal ini sesuai dengan Kemenkes RI tahun 2013 yang menyatakan bahwa salah satu strategi dalam pelaksanaan dan pembinaan pemberdayaan masyarakat dibidang kesehatan adalah adanya pemanfaatan potensi dan sumber daya berbasis kearifan lokal baik dana dan tenaga serta budaya. Dalam hal ini tokoh masyarakat diharapkan menjadi sarana pendukung untuk terlaksananya upaya - upaya pemberdayaan yang dilakukan dengan memberikan dukungan sosial. Dukungan sosial dari tokoh masyarakat dapat berupa adanya kepedulian, perhatian dan perlindungan terhadap konsekuensi yang dihadapi oleh warganya ${ }^{10}$.

Salah satu aspek penting yang belum semua terlaksana di Puskesmas yang diteliti adalah ketersediaan dana masyarakat. Keuangan dalam pemberdayaan masyarakat merupakan barang public (public goods) yang sangat langka dan terbatas, tetapi dana sangat dibutuhkan untuk membiayai banyak kebutuhan dan kegiatan. Ada tiga bidang utama yang dibiayai dengan keuangan masyarakat, salah satunya adalah tentang kemasyarakatan seperti kegiatan LKMD, PKK, pembinaan muda mudi, kelompok tani, keagamaan, kesehatan, penanganan kenakalan remaja, dan lain - lain ${ }^{11}$. Mengacu pada Kemenkes RI tahun 2013, ketersediaan dana merupakan strategi untuk mendukung keberhasilan upaya pemberdayaan masyarakat. Keterbatasan dana menyebabkan banyak kegiatan yang tidak dapat diimplementasikan secara optimal.

Terkait dengan hal ini, diperlukan keaktifan (swadana masyarakat) dan kemitraan masyarakat dengan semua pihak (tokoh masyarakat, unsur pemerintah desa, swasta, dan lain lain) dalam upaya untuk menggali sumber dana. Untuk swadana masyarakat bisa dilakukan dengan cara menghidupkan kembali sumber dana lokal seperti Arisan warga, Tabulin, Tabumas, Iuran Posyandu, dan Iuran warga ${ }^{3}$.

Salah satu contoh kemitraan terkait ketersediaan dana antara lain di beberapa kabupaten/kota seperti Kota Dumai, Provinsi Riau telah melakukan kerjasama dalam bentuk adanya MoU kemitraan masyarakat dengan pihak swasta (perusahaan) dalam hal bantuan dana (dana Coorporate Social Responsibility) untuk membantu kegiatan UKBM..$^{12}$ Selanjutnya, pemerintah juga harus memberikan alokasi dana desa (ADD) sebagai bantuan stimulan atau dana perangsang untuk mendorong kegiatan kemasyarakatan. ${ }^{13}$ Dengan ketersediaan dana ini, maka upaya pemberdayaan masyarakat akan lebih optimal. Hal ini sejalan dengan Kemenkes RI tahun 2013 yang menyatakan bahwa salah satu strategi dalam pelaksanaan dan pembinaan pemberdayaan masyarakat dibidang kesehatan adalah adanya pemanfaatan potensi dan sumber daya berbasis kearifan lokal baik dana dan tenaga serta budaya. ${ }^{14}$

Adapun kegiatan pemberdayaan masyarakat yang paling sedikit dilakukan di wilayah kerja puskesmas adalah pembuatan keputusan oleh masyarakat. Kegiatan pembuatan keputusan oleh masyarakat hanya terdapat di enam dari 10 puskesmas (60\%). Keadaan ini kemungkinan disebabkan oleh kurangnya koordinasi antara berbagai pihak (Puskesmas, tokoh masyarakat, RT/RW, kader posyandu).Kurangnya koordinasi keterlibatan masyarakat akan berdampak pada inefisiesni penyelenggaraan kegiatan pemberdayaan masyarakat oleh puskesmas 
khususnya dalam fungsi pembuatan keputusan oleh masyarakat.

Setelah dilakukan penilaian terhadap kegiatan pemberdayaan masyarakat, maka dilakukan observasi lebih lanjut mengenai jenis organisasi kemasyarakatan dan UKBM yang berjalan di wilayah kerja puskesmas. Berdasarkan hasil penelitian menunjukkan bahwa, dari UKBM yang dilaksanakan hanya posyandu yang berjalan di semua Puskesmas. Untuk posyandu, seluruh puskesmas sudah menerapkan Peraturan Menteri Dalam Negeri No 54 tahun 2007 tentang Pedoman Pembentukan Kelompok Kerja Operasional Pembinaan Pos Pelayanan Terpadu. ${ }^{15}$ Namun,untuk organisasi lain masih ada yang tidak aktif atau tidak dilaksanakan terutama Pondok Bersalin Desa (Polindes). Minimnya jumlah kegiatan polindes bisa disebabkan banyaknya layanan praktek bidan yang ada disekitar puskesmas Kota Pekanbaru maupun puskesmas rawat inap yang melayani ibu yang melahirkan.

Selain tujuh aspek pemberdayaan masyarakat yang telah dijelaskan sebelumnya, perlu juga di perhatikan faktor yang mendukung pelaksanaan fungsi pemberdayaan oleh puskesmas diantaranya ketersedian sumber daya, proses manajerial puskesmas, dan ketersediaan jejaring dan organisasi. Berdasarkan lampiran 3 tabel 3 terlihat bahwa pada ketersediaan sumber daya mayoritas kategori baik terdiri dari 9 puskesmas (90\%) dan 1 Puskesmas (10\%) termasuk kategori cukup. Kondisi ini disebabkan sudah terlaksananya UU RI nomor 32 Tahun 2004 tentang pemerintahan Daerah yang memegang kewenangan penuh dalam bidang kesehatan, seperti revitalisasi Puskesmas dan posyandu dengan pemenuhan fasilitas sarana. Selain itu, faktor pendukung lainnya adalah ketersediaan dana dari pemerintah Kota Pekanbaru yang dapat memenuhi sarana yang dibutuhkan. Hal ini juga sesuai dengan kondisi penerapan model pengembangan lokal yaitu pemberdayaan masyarakat melalui partisipasi masyarakat dengan pengembangan potensi dan sumber daya lokal ${ }^{17}$.

Pada proses manjerial mayoritas kategori baik terdiri dari 9 puskesmas (90\%) dan 1 Puskesmas (10\%) termasuk kategori cukup. Hasil ini memungkinkan dalam suatu proses manajerial bahwa orang yang terlibat didalamnya (kepala puskesmas dan seluruh staff) dituntut atau diharuskan memiliki integritas yang tinggi. Begitu juga dengan organisasi di puskesmas yang ada di Pekanbaru menuntut peran seorang kepala puskesmas harus melakukan kepemimpinan yang efektif karena keberhasilan puskesmas sangat tergantung pada keberhasilan pemimpinnya. Persepsi individu atau staf terhadap pemimpinnya dapat berpengaruh pada perilaku mereka dalam bekerja. Hal ini sesuai dengan pendapat ahli tentang fungsi dari manajemen itu sendiri yaitu sejumlah kegiatan yang meliputi berbagai jenis pekerjaan yang dapat digolongkn dalam satu kelompok sehingga membentuk suatu kesatuan administratif yang terdiri dari memimpin, merencana, menyusun dan mengawas ${ }^{18}$.

Terkait dengan ketersediaan jejaring didapatkan hasil yang belum optimal. Keterlibatan BPP sebagian besar belum ada. Hal ini menunjukkan prinsip penyelenggaraan Puskesmas, yaitu kemandirian masyarakat belum optimal dilakukan. Selain itu juga pada pasal 22 Permenkes no 75 Tahun 2014 dijelaskan bahwa pada Puskesmas kawasan perkotaan harus melibatkan masyarakat dalam penyelenggaraan UKM nya. Kurangnya keterlibatan masyarakat akan berdampak pada inefisiesni penyelenggaraan kegiatan pemberdayaan masyarakat dan akan berkurangnya keterlibatan masyarakat dalam fungsi bantuan pelayanan dan kontrol/pengawasan ${ }^{19}$.

\section{SIMPULAN}

Gambaran aspek pemberdayaan masyarakat di Kota Pekanbaru yang terdiri dari 3 aspek, yaitu keaktifan tokoh masyarakat, ketersediaan organisasi kemasyarakatan dan UKBM, Pemanfaatan sarana dan material dari masyarakat sudah terlaksana secara optimal. Namun, pada 4 aspek: ketersediaan dana masyarakat, penggunaan pengetahuan masyarakat, teknologi dari masyarakat, dan pembuatan keputusan oleh masyarakat belum terlaksana seluruhnya. Penelitian ini juga menunjukkan bahwa masih banyak kegiatan organisasi dan UKBM yang tidak berjalan optimal kecuali posyandu aktif. UKBM polindes masih sangat sedikit dilakukan di wilayah kerja puskesmas di Kota Pekanbaru. Keterkaitan pelaksanaan fungsi pemberdayaan oleh puskesmas dengan sumber daya dan proses manajerial puskesmas sudah dalam kategori baik. Sedangkan pada ketersediaan jejaring dan organisasi masih dalam kategori cukup. Oleh karena itu, perlu dilakukan upaya optimalisasi peran masyarakat dibidang ketersediaan dana, peningkatan pengetahuan serta keputusan oleh masyarakat.

\section{UCAPAN TERIMAKASIH}

Penulis mengucapkan terimakasih kepada Kepala Dinas Kesehatan Kota Pekanbaru, Kepala Puskesmas Se-Kota Pekanbaru, Dekan Fakultas Kedokteran Universitas Riau serta seluruh pihak yang terlibat dalam penelitian untuk mendapatkan izin, data atau informasi yang diperlukan.

\section{DAFTAR PUSTAKA}

1. Kementrian Kesehatan Indonesia. Kepmenkes No 128/Menkes/SK/II/2004 tentang Kebijakan Dasar Puskesmas. (diunduh tanggal 3 November 2016. Tersedia www.hukor.depkes.go.id/hukor/0/2014/14)

2. Dinas Kesehatan Kota Pekanbaru. Profil Dinas Kesehatan Pekanbaru Tahun 2014. Pekanbaru: Dinas Kesehatan Kota Pekanbaru, 2014.

3. Darmawan, Ede Surya. Mengukur Tingkat Pemberdayaan Masyarakat dalam Sektor Kesehatan. Jurnal Kesehatan Masyarakat 2012;7(2):91-96.

4. Kementerian Kesehatan Republik Indonesia tahun 1999, tentang panduan umum pemberdayaan masyarakat

5. Adisasmito, W. Sistem Kesehatan.Jakarta, DKI, Indonesia: Pustaka Nasional. 2007.

6. Laverack, G., \& Wallerstein, N. . Measuring community empowerment: a fresh look at organizational domains. Helath Promotion International.2001;16(2):179-185.

7. Kementrian Kesehatan Republik Indonesia.Perkembangan dan tantangan promosi kesehatan di Indonesia: dari propaganda sampai promosi kesehatan.Jakarta : Kementrian Kesehatan Republik Indonesia; 2009.

8. Kementrian Kesehatan Republik Indonesia.Keputusan Mentri Kesehatan Republik Indonesia nomor.1529/Menkes/SK/x/2010 tentang pedoman umum pengembangan desa dan kelurahan siaga aktif.Jakarta; Kementrian Kesehatan Republik Indonesia; 2010. 
9. Notoadmodjo S. Pendidikan dan Perilaku Kesehatan. Jakarta; Rineka Cipta, 2007;22-26

10. Sarason, BarbaraR, Irwin G. Pierce : Social Support : An Interactional View. John \& Sons, 1990.

11. Anonim, 2015. Pengelolaan Keuangan Desa dalam Kerangka Tata Pemerintahan Yang Baik. http://www.keuangandesa.com/2015/04/pengelola an-keuangan-desa-dalam-kerangka-tata-

pemerintahan-yang-baik/ diakses pada 2 November 201615.30 WIB

12. Zahtamal, Restuastuti T, Chandra F. Analisis Faktor Determinan Permasalahan Pelayanan Kesehatan Ibu dan Anak. Kesmas. 2011;6(1): 9-16.

13. BAURA J, Mandey J, \& Tulusan F. Pemberdayaan Masyarakat Dalam Pemanfaatan Alokasi Dana (ADD)(Suatu Studi Di Desa Bukumatiti Kecamatan Jailolo Kabuapten Halmahera Barat). Jurnal Administrasi Publik. 2015;4(32).

14. Kementrian Kesehatan Republik Indonesia. Permenkes nomor 65 tahun 2013 tentang Pedoman pelaksanaan pemberdayaan masyarakat bidang kesehatan, 2013(diunduh tanggal 2 November 2016. Tersedia di www.hukor.depkes.go.id)

15. Kemendagri RI. Peraturan Menteri Dalam Negeri No 54 tahun 2007 tentang Pedoman Pembentukan Kelompok Kerja Operasional Pembinaan Pos Pelayanan Terpadu (diunduh tanggal 2 November 2016. Tersedia di www.kemendagri.go.id)

16. UU Republik Indonesia no 32 Tahun 2004 tentang Pemerintahan Daerah. (diunduh tanggal 3 November 2016. Tersedia di www.kpu.go.id)

17. Fleming, Lee dan David M.Waguespack. Brokerage, Boundary Spanning, and Leadership in Open Innovation Comunities. Organization science. 2007;65- 180

18. Muninja, A.A Gde. Manajemen Kesehatan. Bali : Penerbit Buku Kedokteran. 2004.

19. Kemenkes RI. Undang - undang No 75 Tahun 2014 tentang Pusat Kesehatan Masyarakat (diunduh tanggal 3 November 2016. Tersedia di www.hukor.depkes.go.id) 